\title{
Heavy Metal Pollution Investigation of Left Bank Outfall Drain of Coastal District Badin, Sindh, Pakistan by Using Arc GIS
}

\author{
Mohammad Amin Qureshi, ", Ghulam Murtaza Mastoi ${ }^{1}$, Zulfiqar Ali Laghari \\ Khalid Hussain Lashari ${ }^{3}$, Fouzia Panhwar ${ }^{4}$, Zameer Ali Palh ${ }^{3}$ \\ ${ }^{1}$ Centre for Environmental Sciences, University of Sindh, Jamshoro, Sindh, Pakistan \\ ${ }^{2}$ Department of Physiology, University of Sindh, Jamshoro, Pakistan \\ ${ }^{3}$ Department of Fresh Water Biology and Fisheries, University of Sindh, Jamshoro, Pakistan \\ ${ }^{4}$ Department of Pharmacology, University of Sindh, Jamshoro, Pakistan
}

\section{Email address:}

m-ameen-q@hotmail.com(M. A.Qureshi)

\section{To cite this article:}

Mohammad Amin Qureshi, Ghulam Murtaza Mastoi, Zulfiqar Ali Laghari, Khalid Hussain Lashari, Fouzia Panhwar, Zameer Ali Palh. Heavy Metal Pollution Investigation of Left Bank Outfall Drain of Coastal District Badin, Sindh, Pakistan by Using Arc GIS. International Journal of Environmental Monitoring and Analysis. Vol. 3, No. 3, 2015, pp. 122-132. doi: 10.11648/j.ijema.20150303.13

\begin{abstract}
Coastal district Badin of Sindh Pakistan is known as hub of pollution because of surface drain canal network, which continuously carries industrial effluents, municipal wastes, pumped saline water and excess agriculture water of three districts. Agriculture lands, ground water, lakes and Lagoons of the district have been contaminated with toxic heavy metals due to improper infrastructure of Left Bank Outfall Drain. The object of this study was to study the pollution contributed by drains of coastal areas of Badin. Nineteen samples of water were collected from different locations of drains on quarterly basis. Arc GIS was applied for vector mapping. Average results of parameters were EC $5.975 \pm 4.956 \mathrm{mS} / \mathrm{cm}, \mathrm{TDS} 3254.17 \pm$ $2810.342 \mathrm{mg} / \mathrm{L}, \mathrm{Hg} 0.0234 \pm 0.0118 \mu \mathrm{g} / \mathrm{L}, \mathrm{Ni} 0.0076 \pm 0.0106 \mathrm{mg} / \mathrm{L}, \mathrm{Cd} 0.0245 \pm 0.0179 \mathrm{mg} / \mathrm{L}, \mathrm{Zn} 0.0393 \pm 0.0254 \mathrm{mg} / \mathrm{L}, \mathrm{Cu}$ $0.0890 \pm 0.0911 \mathrm{mg} / \mathrm{L}, \mathrm{Fe} 0.0546 \pm 0.0883 \mathrm{mg} / \mathrm{L}$. The results indicated that all parameters were within National Environmental Quality Standards (NEQS) limits of Pakistan for Industrial effluents. High concentration of TDS, and E.C, near thecoastal sampling areas, confirmed that, sea water has been facilitated, with backward flow by same drains due to sea tides. Heavy metal results were also within permissible limits of Food Agriculture Organization (FAO) for agriculture use. Drain water may be used for saline agriculture purpose, if properly checked under Environmental Protection Act of Pakistan 1997.
\end{abstract}

Keywords: LBOD (Left Bank Outfall Drain),Coastal Area of Badin, GIS (Geographic Information System), Industrial Effluent, KPOD (Kadhan Pateji Outfall Drain), DPOD (Dhoro Puran Outfall Drain)

\section{Introduction}

The river Indus of Pakistan irrigates 35.7 million acres of land. The irrigation network system has also given rise to water logging and salinity threats to agriculture, with passage of time. The coastal areas have been adversely affected .The Left bank outfall drain (LBOD) project was implemented from 1987 to 1997. The project was to mitigate water logging and salinity of 1.27 million acres of three districts, of Sindh province. The LBOD initially was aimed to drain out pumped saline water and agricultural runoff but municipal and industrial wastewas also thrown in this drain. The coastal district Badin became the final path way of this contaminated water to Arabian Sea. LBOD has a total discharge capacity of 4400 cusec and flows throughout the year $[1,2,3]$.

LBOD is bifurcated into two main surface drains named KPOD (KadhanPateji Outfall Drain) and DPOD (DhoroPuran Outfall Drain). DPOD discharges into Shakoor Lake which is a joint Lakeof Pakistan and India (Fig.1).KPOD, flows with damaged infra structurepath of Tidal Link and Cholri Weir, reaches at Shah Samdo Creek and finally joins ArabianSea. It contaminates all wetlands of the coastal areas.Cholri weir and Tidal link, the important components of LBOD were constructed to maintain wet lands and high tides of sea. Both infrastructures became completely damaged after cyclone of $1999[1,2,3,4,5$, 6].Consequently sea tidal water got quick access to wards 
inland areas which was not possible before. Hence the ecology of the coastal areas, mostly of wetlands, has been completely changed since two decades[7, 8].The World Bank was a major contributor of finance and technical assistance of the mega project, LBOD. The World Bank's Panel in 2005-6 reported that the failure of LBOD project was due to faulty design, underestimating the extreme meteorological risks and improper follow up of the recommended policies and procedures[9, 10, 3].The Panel also concededthat the little attention had been paid to the impacts on the environmentally important and Ramsar recognized coastal lakes and lagoons [10].This study was conducted to investigate the heavy metal pollution, carried by LBOD and other link surface drains near the coastal lines of Badin. At the same time to find out pollution contributed by sea tidal water from Arabian Sea.The results were compared with permissible limits of NEQS of Pakistan for municipal and industrial effluent. The results were interpreted by using Arc GIS application.

\section{Experimental}

\subsection{History Background of Area of Study}

Badin is positioned between $24^{\circ}-5^{\prime}$ to $25^{\circ}-25^{\prime}$ north latitude and $6821^{\prime}$ 'to $6920^{\prime}$ east longitude [5].The district joins in south with the Arabian Sea and Rann of Kutch. The agriculture and agro based industry are the sources of economy. Coastal district of Badin is a flat, flood prone land, where required fresh canal water does not reach.The land and groundwater are saline. Climate of this area is unreliableand has proved to be very fatal to natives.Badin is situated in Zone II with respect to cyclonic activity which suggests that the district is exposed to tropical cyclones[2]. Stormy cyclones, monsoon rains, earthquakes and droughtshave aggravated already deteriorated conditions of the coastal areas.

Ecological degradation of Badin coastal area is result of neglecting attitude, considering this area, only a hub and pathway for disposable liquid waste towards Arabian Sea.Environmental, socio economical issues of these areas have never been taken properly and seriously. Deteriorated condition of this region is due to, two main surface drain system introduced in this area in 1960s and 1980s. Kotri Barrage drain system fromT.M.Khan,comprised of KaroGhungro(1960) and FuleliGuni(1959) Outfall drains, both drains, enter from west side of district,polluting coastal wet lands.FulleliGuni outfalls drain ends into MehroLake. KaroGhungro surface drainage System ends in Sanhro Lake. Both lakes are part of Ramsar recognized Jabholagoon (Fig. 1).Both drains carrying sugar mill effluents along with agriculture runoff, reducing bio life of wetlands[1, 2, 3, 6, 7].

The contaminated water of Kotri drain and LBOD, meet at saline Cholri shallow lake. It is zone of mixed polluted water (Fig. 1).A hub of pollution sink has been developed mostly after the destruction of Cholri weir and disappearance of tidal link after cyclone 1999[7].Costal tidal water strikes near village Golo Mandhro boundary wall at present time (Fig1).

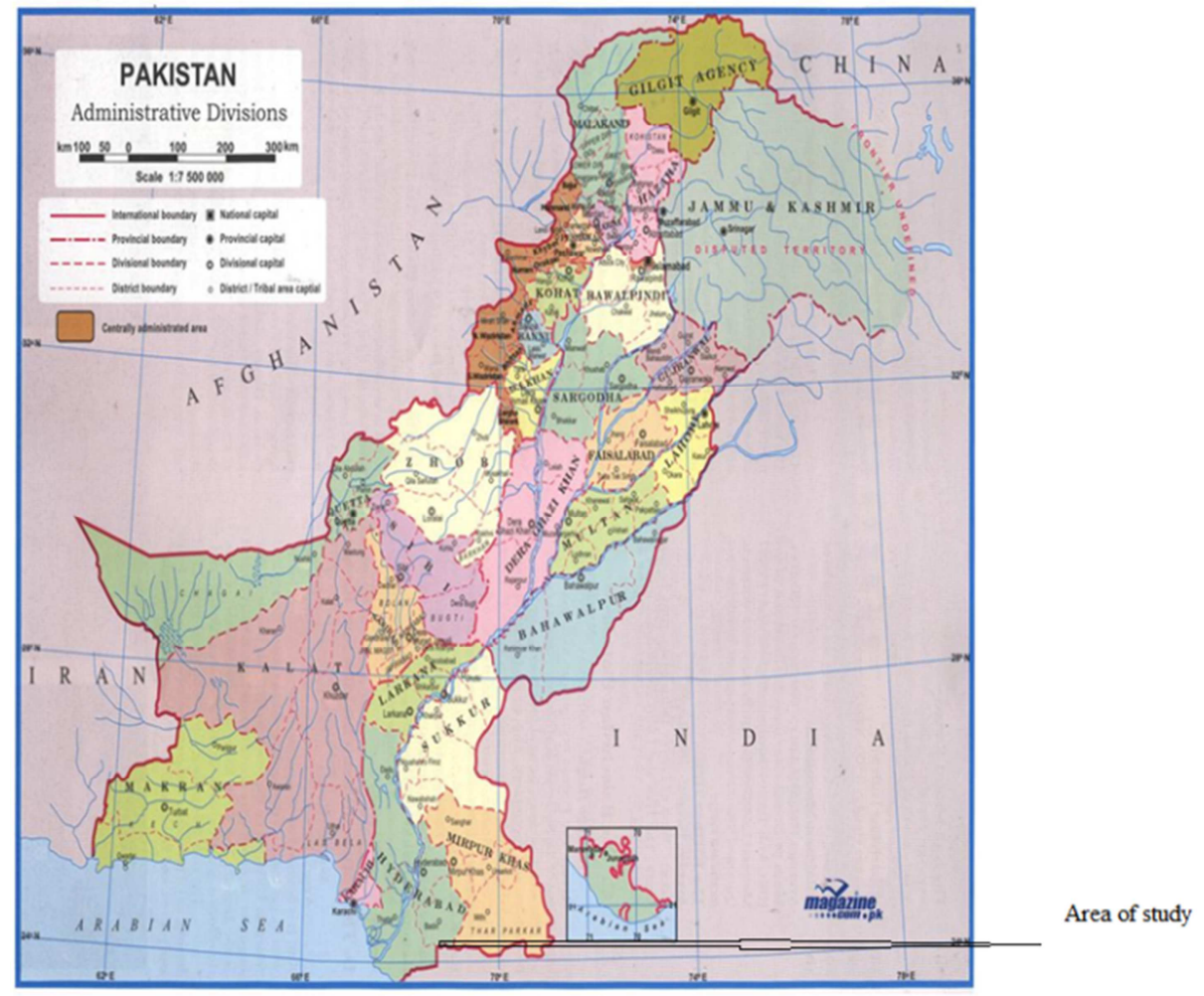




\section{Coastal Area Badin}

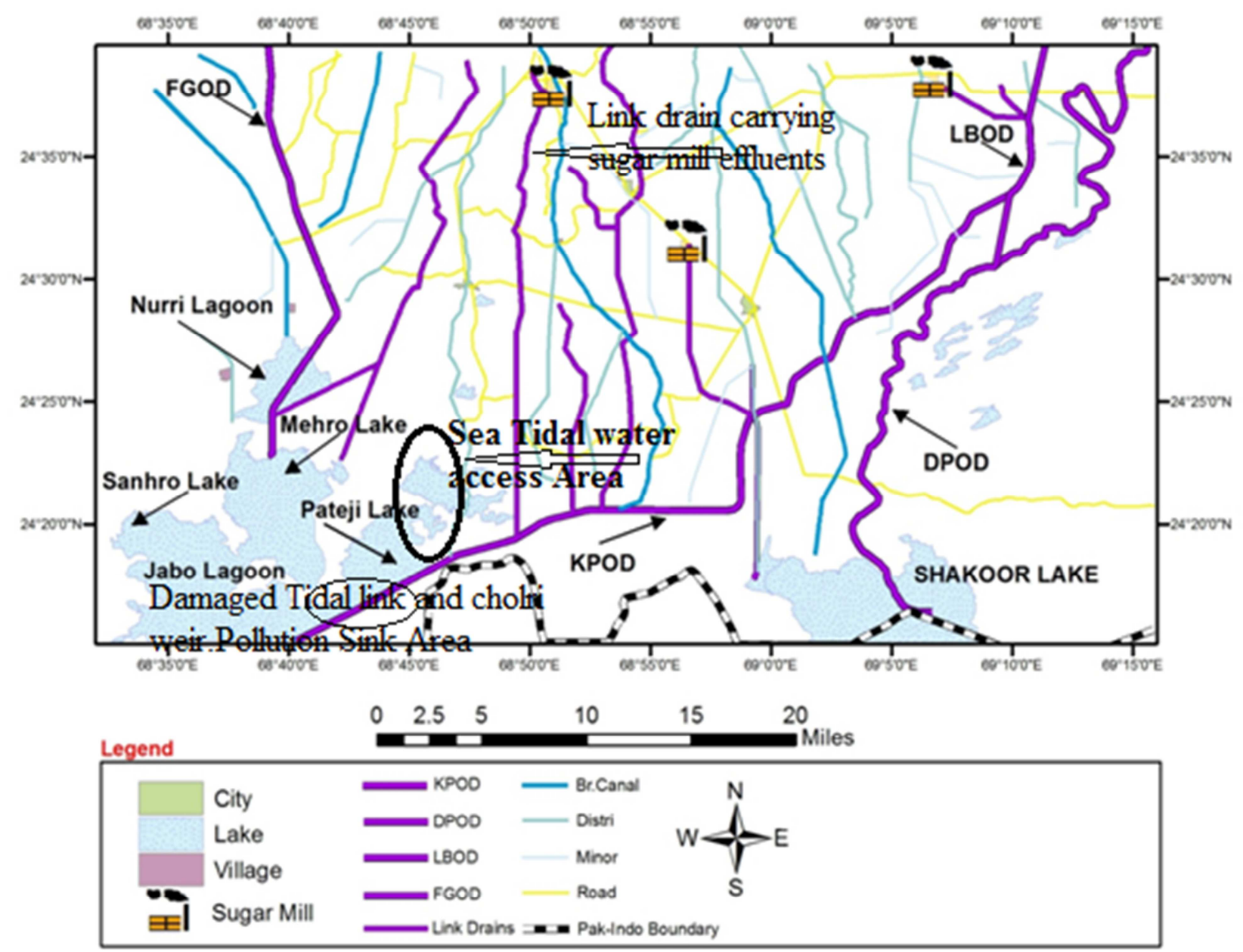

Fig. 1. Base map of area study.

\subsection{Sample Collection}

Nineteen surface drain water samples, with three replicates, were collected from the coastal belt of district Badin, after every three months (March, June, September and December) throughout the year 2013. Samples were collected from 9 am to $4 \mathrm{pm}$.

\subsection{Method}

Samples were collected in previously clean $1.5 \mathrm{~L}$ plastic bottles, temperature of air and water, electric conductivity, total dissolved salts, readings weretaken on the spot. Latitude and longitude were recorded by using GPSeTrex Legend Garmin. EC, TDS, of water samples was measured using pre calibrated Orion 115 conductivity meter [11]. Iron, Copper, Zinc, Cadmium, Nickel, Mercurry, concentrations were determined using Flame Atomic Absorption Spectrophotometer and Mercury by cold vapor method by Flame Atomic Absorption Spectrophoto-meter (FAAS) [11].

GIS is apowerful tool for collecting, storing, organizing, transforming and displaying data, for specific aims from the real world $[12,13,14]$.GIS is increasingly used in Environmental pollution studies because of its ability in spatial analysis and understanding thematic maps [15, 16].Arc GIS 9.2 software was used for mapping and data interpretation. Arc GIS software was applied in this study as an important analyzing tool. Based on the sampling locations, with the utilization of coordinates of GPS, a point feature map showing the position of sampling location was prepared. By using Arc map of arc GIS software, Monitored water quality data was stored as attribute table.Graduated symbols and colors were selected using symbology option.

\section{Result}

Average results ( Table 3 ) of surface drains of coastal area of Badin indicated the obtained \% concentration range of parameters studied were $\mathrm{TDS}(\mathrm{mg} / \mathrm{L}) \quad 92.9 \% \quad, \quad \mathrm{Hg}$ $(\mu \mathrm{g} / \mathrm{L}) 0.234 \%$, Ni (mg/L)0.76\% , Cd (mg/L) $24.5 \%$, $\mathrm{Zn}(\mathrm{mg} / \mathrm{L}) 0.786 \%, \mathrm{Cu}(\mathrm{mg} / \mathrm{L}) 8.9 \%, \mathrm{Fe}(\mathrm{mg} / \mathrm{L}) 0.68 \%$ in comparison to defined limits of NEQS for Industrial effluents of Pakistan. 


\section{Discussions}

The resultsof Electric Conductivity concentration indicated in Fig. 2, represented by graduated circles and colors.Red color circle symbol was selected to high light obtained results in four classes. Electric Conductivityof sampling areas waswithin range 1.298- $21.775 \mathrm{mS} / \mathrm{cm}$ (table1\&2). E.C was alarmingly high at S-I, S-2, S-9, S-18, S-19, locations.The
E.C was found to be high near coastal sea water. An increasing trend is seen as KPOD drain flow reaches near damaged cholri weir and tidal link area.This confirmed that coastal area was not only polluted by drainsbut back flow of sea water through tidal waves was also a major contributor (Fig. 1). Our results of EC (1.298-21.775 mS/cm) were found very high as compared toWorld Bankreport indicatingEC range from $624-685 \mathrm{mS} / \mathrm{cm}$ of KPOD [3].

Table 1. Showing heavy metal results of drains of coastal area of Badin.

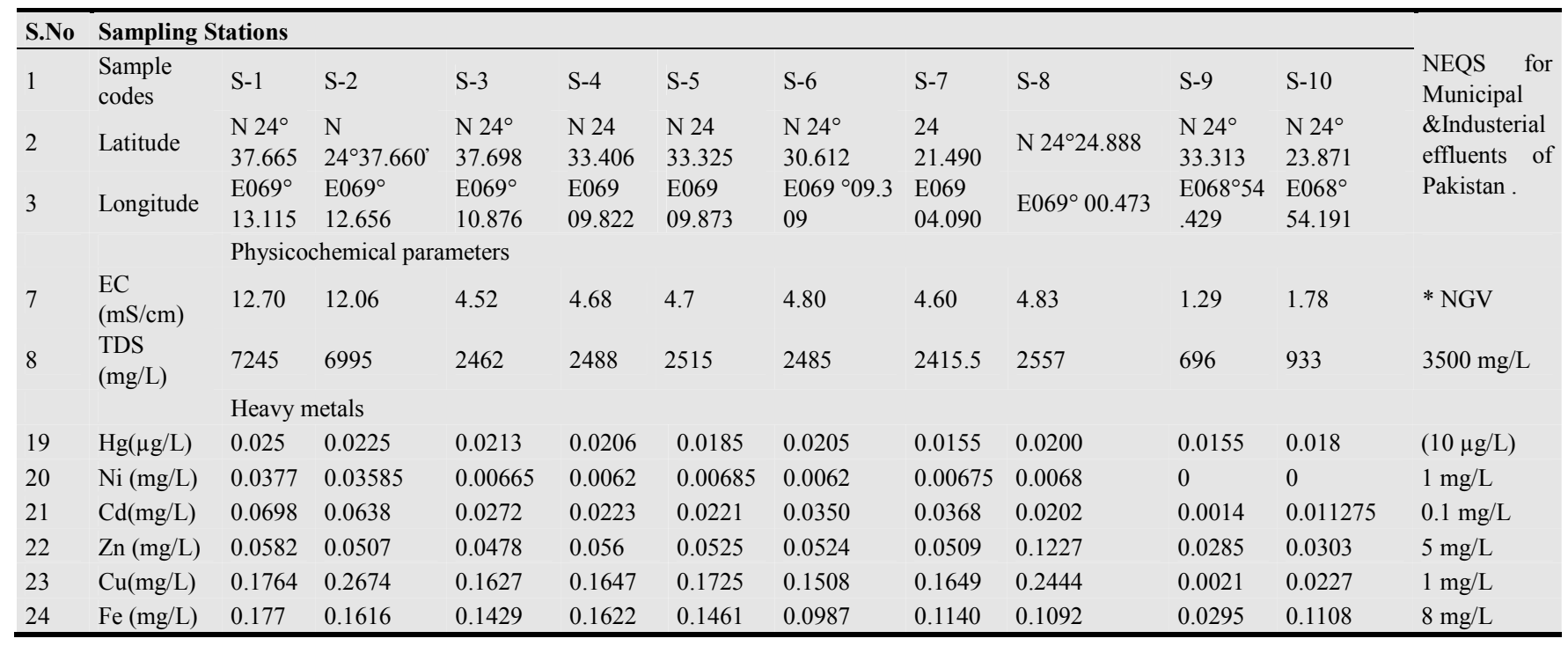

Table 2. Showing heavy metal results of drains of coastal area of Badin.

\begin{tabular}{|c|c|c|c|c|c|c|c|c|c|c|c|}
\hline \multirow{2}{*}{$\begin{array}{l}\text { S.No } \\
1\end{array}$} & \multicolumn{10}{|c|}{ Sampling stations } & \multirow{6}{*}{$\begin{array}{l}\text { NEQS for } \\
\text { Municipal \& } \\
\text { Industrial } \\
\text { effluents of } \\
\text { Pakistan. }\end{array}$} \\
\hline & $\begin{array}{l}\text { Sample } \\
\text { codes }\end{array}$ & S-11 & S-12 & S-13 & S-14 & S-15 & S-16 & S-17 & S-18 & S-19 & \\
\hline \multirow[t]{2}{*}{2} & & $\mathrm{~N} 24^{\circ}$ & $\mathrm{N}$ & $\mathrm{N}$ & $\mathrm{N}$ & $\mathrm{N} \quad 24^{\circ}$ & $\mathrm{N}$ & $\mathrm{N}$ & $\mathrm{N}$ & & \\
\hline & Latitude & 24.122 & $24^{\circ} 29.519$ & $24^{\circ} 30.143$ & $24^{\circ} 24.204$ & 18.528 & $24^{\circ} 17.990$ & $24^{\circ} 17.490$ & $24^{\circ} 17.000$ & $24^{\circ} 16.652$ & \\
\hline \multirow[t]{2}{*}{3} & Lonoitude & $\mathrm{E} 068^{\circ}$ & $\mathrm{E} 068^{\circ}$ & E068ํ․ 45.4 & $\mathrm{E} 068^{\circ}$ & $\mathrm{E} 068^{\circ}$ & $\mathrm{E} 068^{\circ}$ & $\mathrm{E} 068^{\circ} 44.6$ & $\mathrm{E} 068^{\circ} 43.7$ & E0684․ 43 & \\
\hline & Longitude & 49.473 & 41.643 & 47 & 39.332 & 46.514 & 45.600 & 85 & 91 & 1 & \\
\hline \multicolumn{12}{|c|}{ Physicochemical parameters } \\
\hline 7 & $\begin{array}{l}\mathrm{EC} \\
(\mathrm{mS} / \mathrm{cm})\end{array}$ & 1.76 & 3.38 & 1.81 & 3.04 & 5.51 & 5.47 & 5.63 & 9.12 & 21.77 & * NGV \\
\hline \multirow[t]{2}{*}{8} & $\begin{array}{l}\text { TDS } \\
(\mathrm{mg} / \mathrm{L})\end{array}$ & 889.5 & 1833.75 & 943.75 & 1557.5 & 2856.5 & 2887.5 & 3007.5 & 5000.5 & 12060 & $3500 \mathrm{mg} / \mathrm{L}$ \\
\hline & & \multicolumn{9}{|c|}{ Heavy metals (mg/L) } & \\
\hline 19 & $\mathrm{Hg}(\mu \mathrm{g} / \mathrm{L})$ & 0.0147 & 0.023 & 0.021 & 0.0262 & 0.0553 & 0.0526 & 0.0308 & 0.0149 & 0.0086 & $(10 \mu \mathrm{g} / \mathrm{L})$ \\
\hline 20 & Ni (mg/L) & 0.0020 & 0.0012 & 0.0021 & 0.0016 & 0.0059 & 0.0086 & 0.0049 & 0.0061 & 0 & $1 \mathrm{mg} / \mathrm{L}$ \\
\hline 21 & $\mathrm{Cd}(\mathrm{mg} / \mathrm{L})$ & 0.0170 & 0.0142 & 0.0179 & 0.0202 & 0.0349 & 0.0226 & 0.0207 & 0.0092 & 0 & $0.1 \mathrm{mg} / \mathrm{L}$ \\
\hline 23 & $\mathrm{Cu}(\mathrm{mg} / \mathrm{L})$ & 0.0102 & 0.0171 & 0.0161 & 0.0357 & 0.0297 & 0.0216 & 0.0152 & 0.0126 & 0.0042 & $1 \mathrm{mg} / \mathrm{L}$ \\
\hline 24 & $\mathrm{Fe}(\mathrm{mg} / \mathrm{L})$ & 0.0317 & 0.0234 & 0.0276 & 0.1194 & 0.0715 & 0.0574 & 0.0378 & 0.0459 & 0.0112 & $8 \mathrm{mg} / \mathrm{L}$ \\
\hline
\end{tabular}

* NGV (No health-based guideline value recommended by NEQS of Pakistan).

Table 3. Showing average and St.Dev with min. max.

\begin{tabular}{|c|c|c|c|c|c|c|c|c|}
\hline & $\begin{array}{l}\text { E.C }(\mathrm{mS} / \\
\mathrm{cm})\end{array}$ & TDS(mg/L) & $\mathrm{Hg}(\mu \mathrm{g} / \mathrm{L})$ & $\mathrm{Ni}(\mathrm{mg} / \mathrm{L})$ & $\mathrm{Cd}(\mathrm{mg} / \mathrm{L})$ & $\mathrm{Zn}(\mathrm{mg} / \mathrm{L})$ & $\mathrm{Cu}(\mathrm{mg} / \mathrm{L})$ & $\mathrm{Fe}(\mathrm{mg} / \mathrm{L})$ \\
\hline Average & 5.975 & 3254.17 & 0.0234 & 0.0076 & 0.0245 & 0.0393 & 0.0890 & 0.0546 \\
\hline St.Dev. & 4.956 & 2810.342 & 0.0118 & 0.0106 & 0.0179 & 0.0254 & 0.0911 & 0.0883 \\
\hline Min & 1.298 & 696 & 0.0086 & 0.0012 & 0.00148 & 0.0093 & 0.00215 & 0.011225 \\
\hline Max & 21.775 & 12060 & 0.05535 & 0.037775 & 0.069825 & 0.12275 & 0.267475 & 0.177 \\
\hline
\end{tabular}




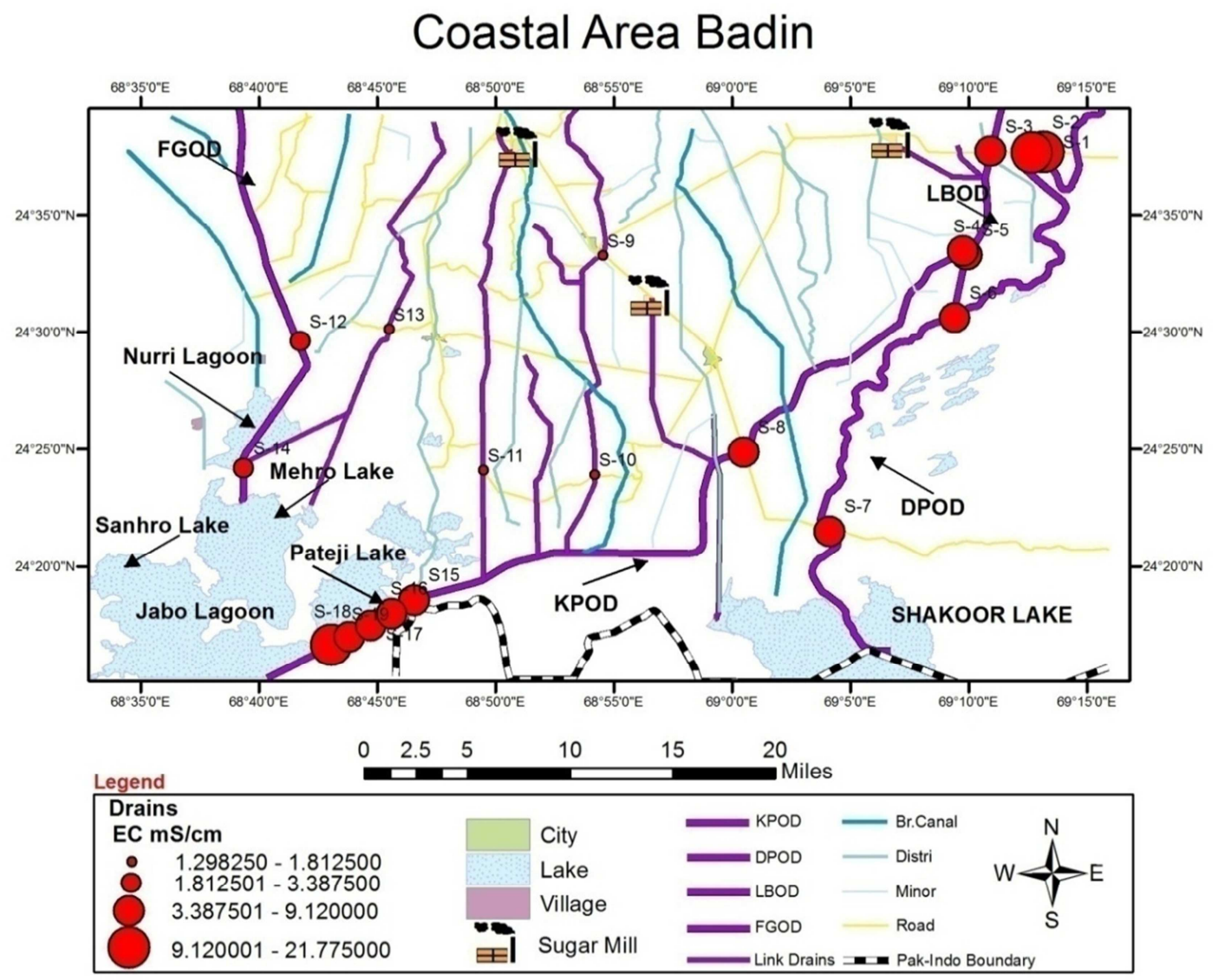

Fig. 2. Map showing detection of E.C.

Coastal Area Badin

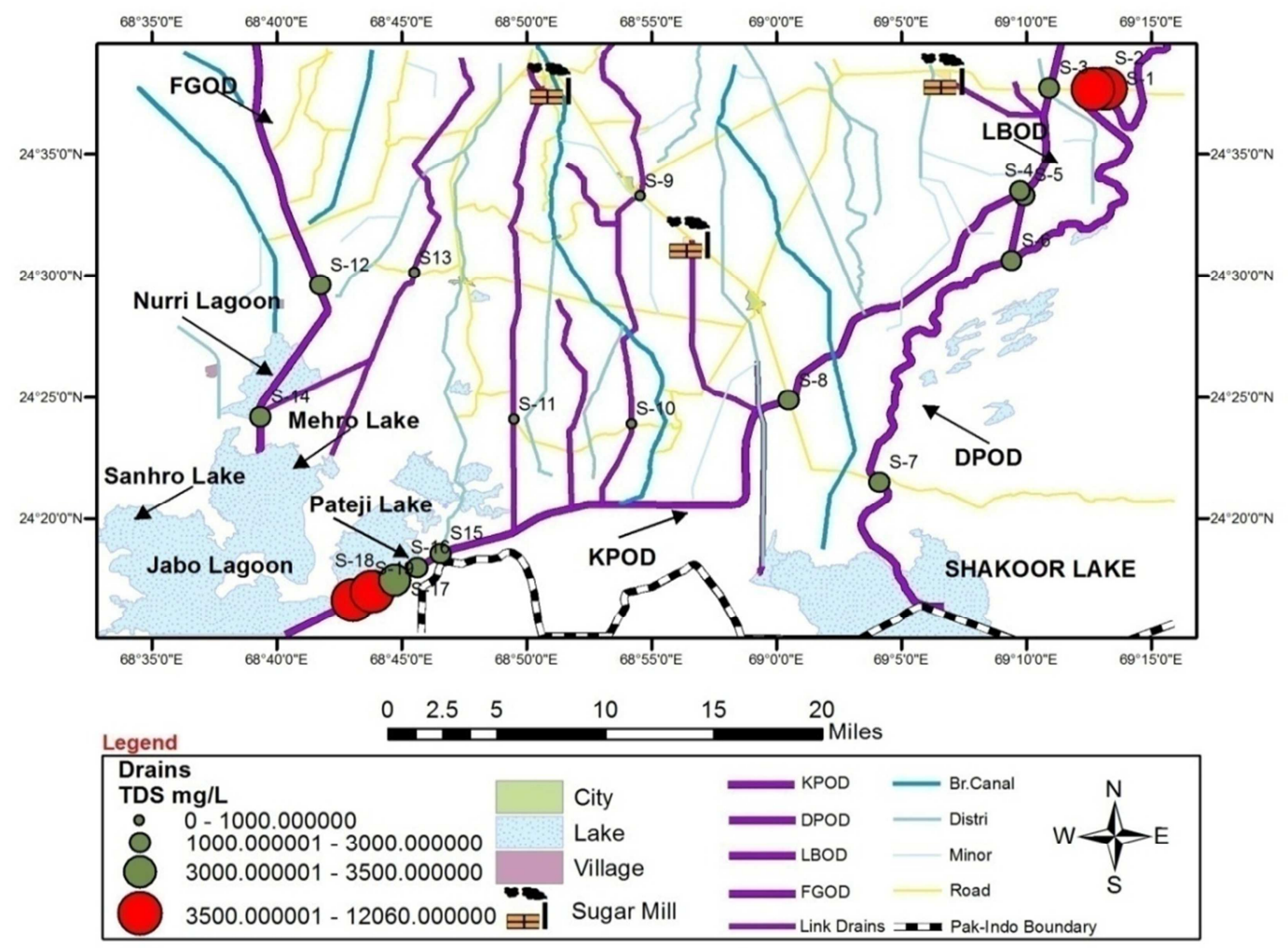

Fig. 3. Map showing TDS detection. 
The results of TDS are shown in Fig.3, showing different ranges of concentrations from 696 - $12060 \mathrm{mg} / \mathrm{L}$. Results were divided into four classes with graduated circles, represented by green and red colors. Green color was selected for representing permissible limit values $(3500 \mathrm{mg} / \mathrm{L})$ forNEQS of Pakistan for industrialeffluents.The concentration above NEQS limit was indicated by color red. Sampling areas of S-1, S-2, S-18, S-19(table1 \& 2), had high concentrations of TDS than the NEQS limits for industrial and municipal effluents. Samples S-18 and S-19 were closer to damaged tidal link area of LBOD, which was linked to Arabian Sea by shah SamdoCreek (Fig1).Increasing trend of TDS was seen close to coastal areas. The same trends continue, as was reported for, Amir Shah Drain of Badin coast, which had TDS concentration range within $4221 \mathrm{mg} / \mathrm{L}$ [2].

The result of concentration of Mercury indicated in fig 4, with graduated circles. The concentration of $\mathrm{Hg}$ range was found to be between $0.0086-0.05535 \mu \mathrm{g} / \mathrm{L}$ (table 3 ). Mercury, represented with green color, was in all sampling locations within defined limit of NEQS $(10 \mu \mathrm{g} / \mathrm{L})$ for industrial effluents. The concentration of mercury reduced on moving closer to coastal sea water. The reduced concentration of mercury may be due to huge quantity of water, where mercury concentration gets diluted.

The concentration of Nickel as shown in Fig. 5, highlighted by graduated circles, with green color, by using symbology from arc map. Nickel concentration results $(0.0012-0.0377 \mathrm{mg} / \mathrm{L})$, were within describedpermissible limits $(1 \mathrm{mg} / \mathrm{L})$ of NEQS.It was observed that near damaged tidal link area, where huge coastal tidal water intrudes towards wetlands (Fig. 01), nickel concentration was found to be reduced. Theresults are in agreement withstudy conducted bySaif et al. [17].

\section{Coastal Area Badin}

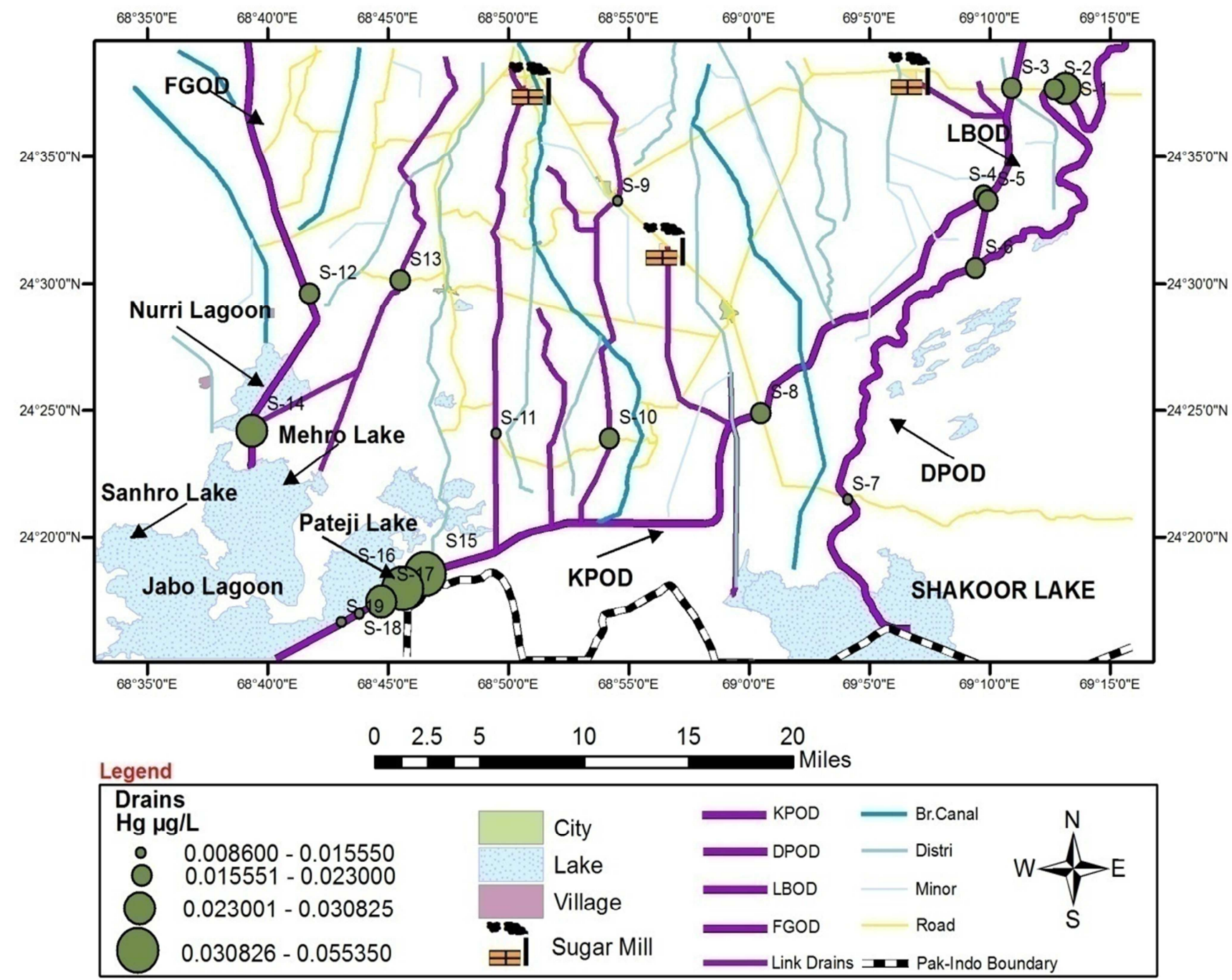

Fig. 4. Map showing detection of mercury. 


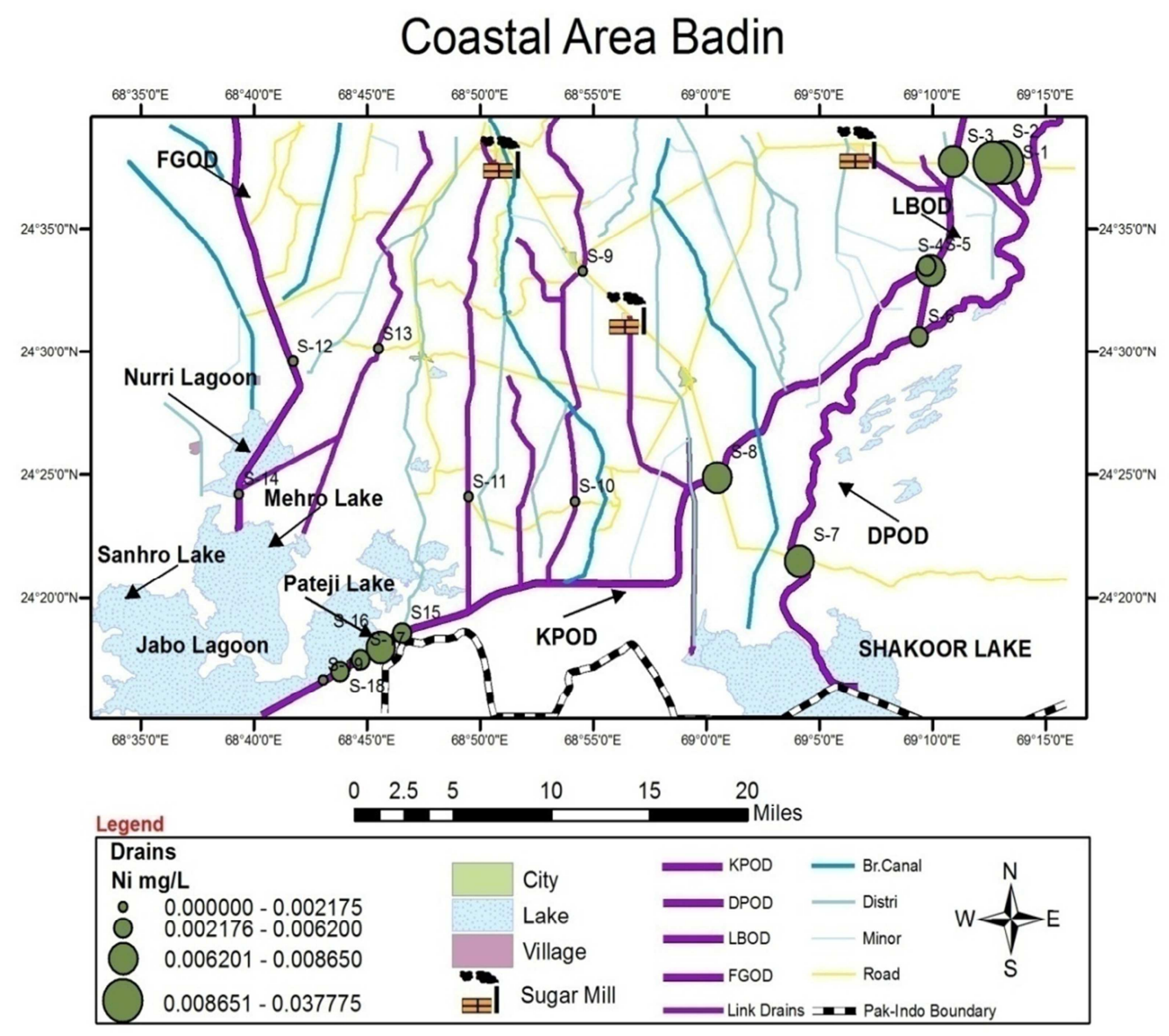

Fig. 5. Map showing areas for Ni detection.

\section{Coastal Area Badin}

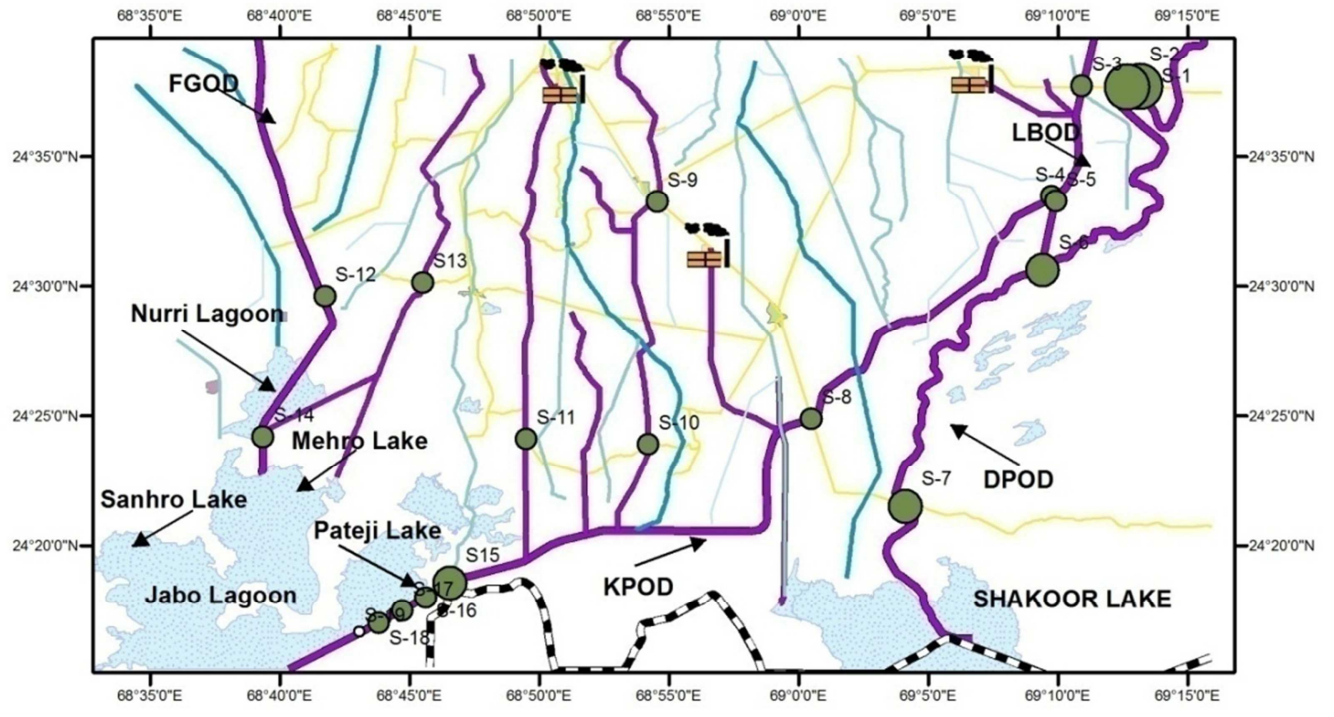

$\begin{array}{lll}0 & 2.5 \quad 5\end{array}$

$\begin{array}{lll}0 & 15 & 20 \\ & & \end{array}$

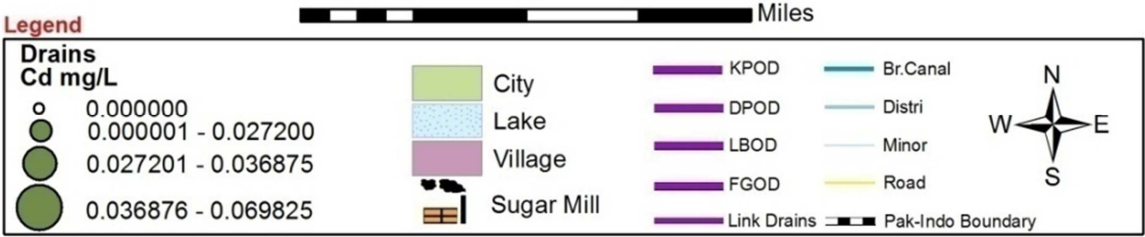

Fig. 6. Map showing results of Cadmium detection. 
Coastal Area Badin

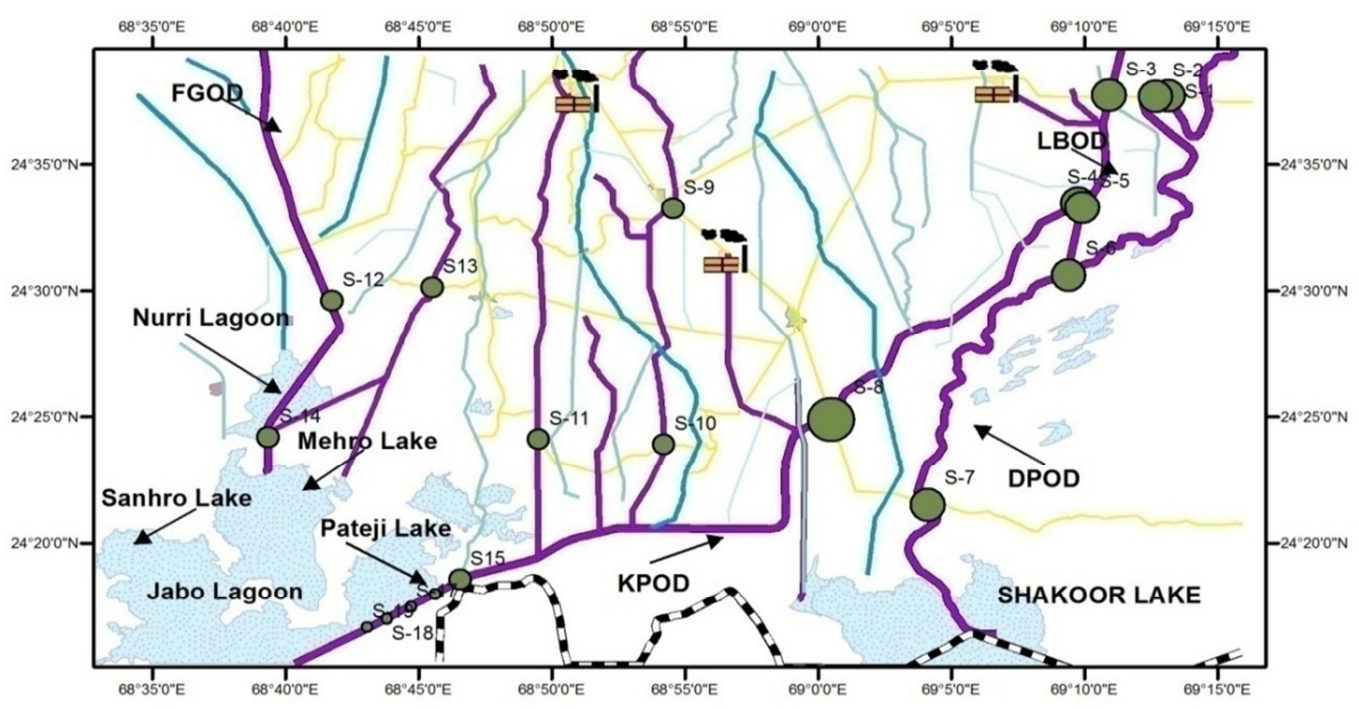

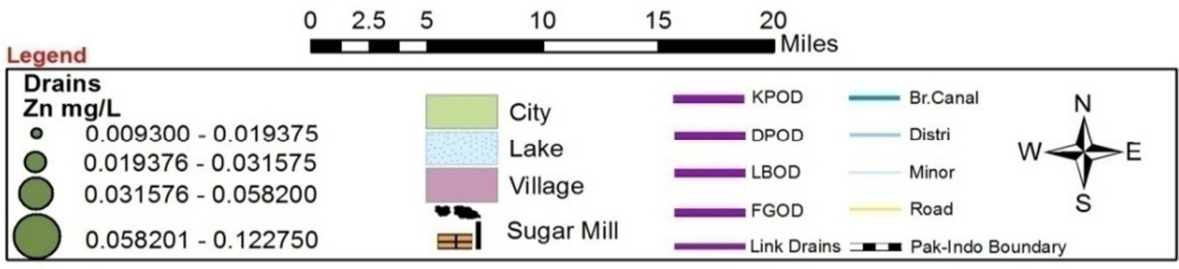

Fig. 7. Map showing detected Zinc.

Coastal Area Badin

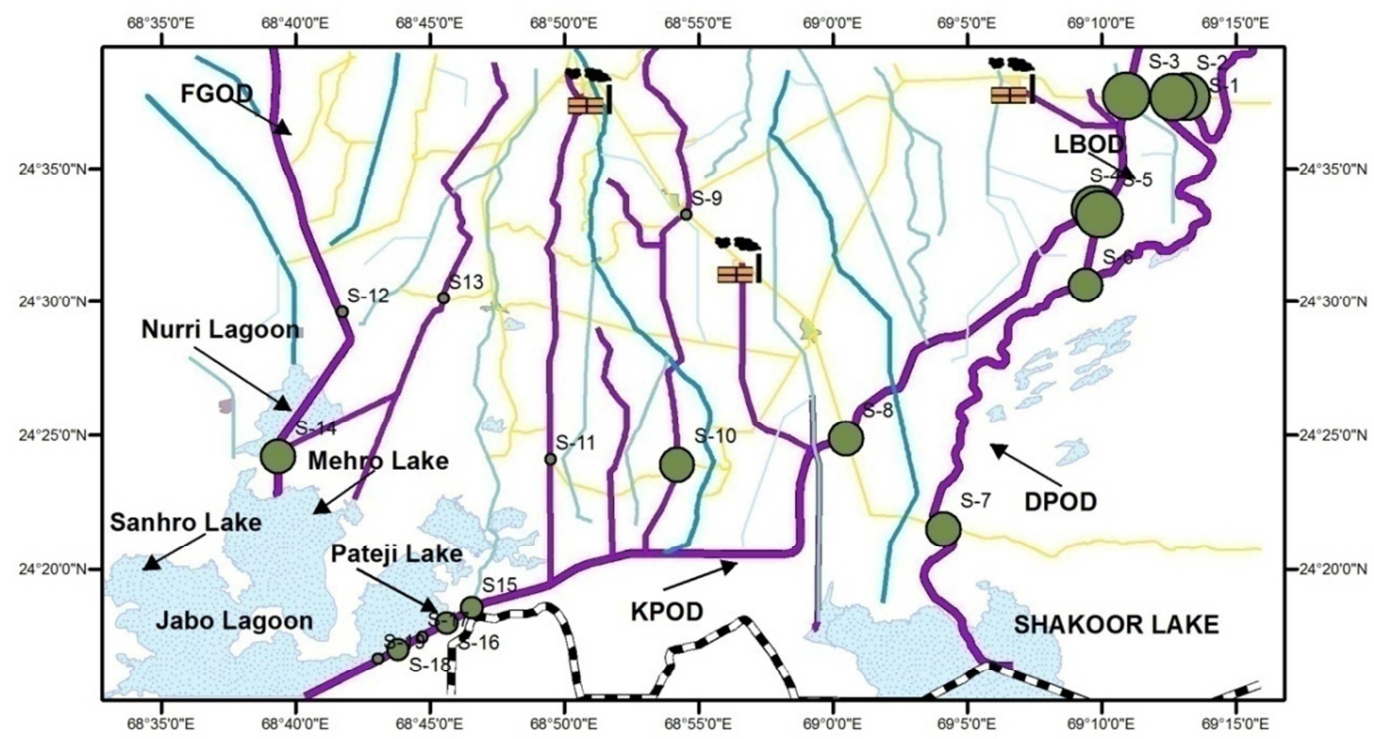

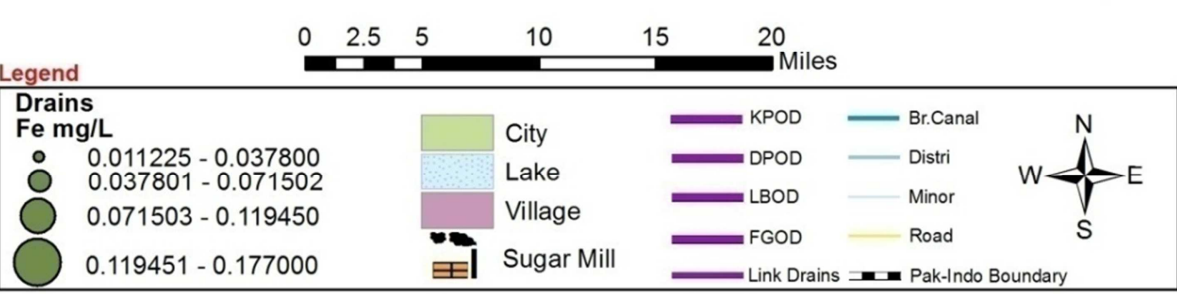

Fig. 8. Showing detection of Iron. 


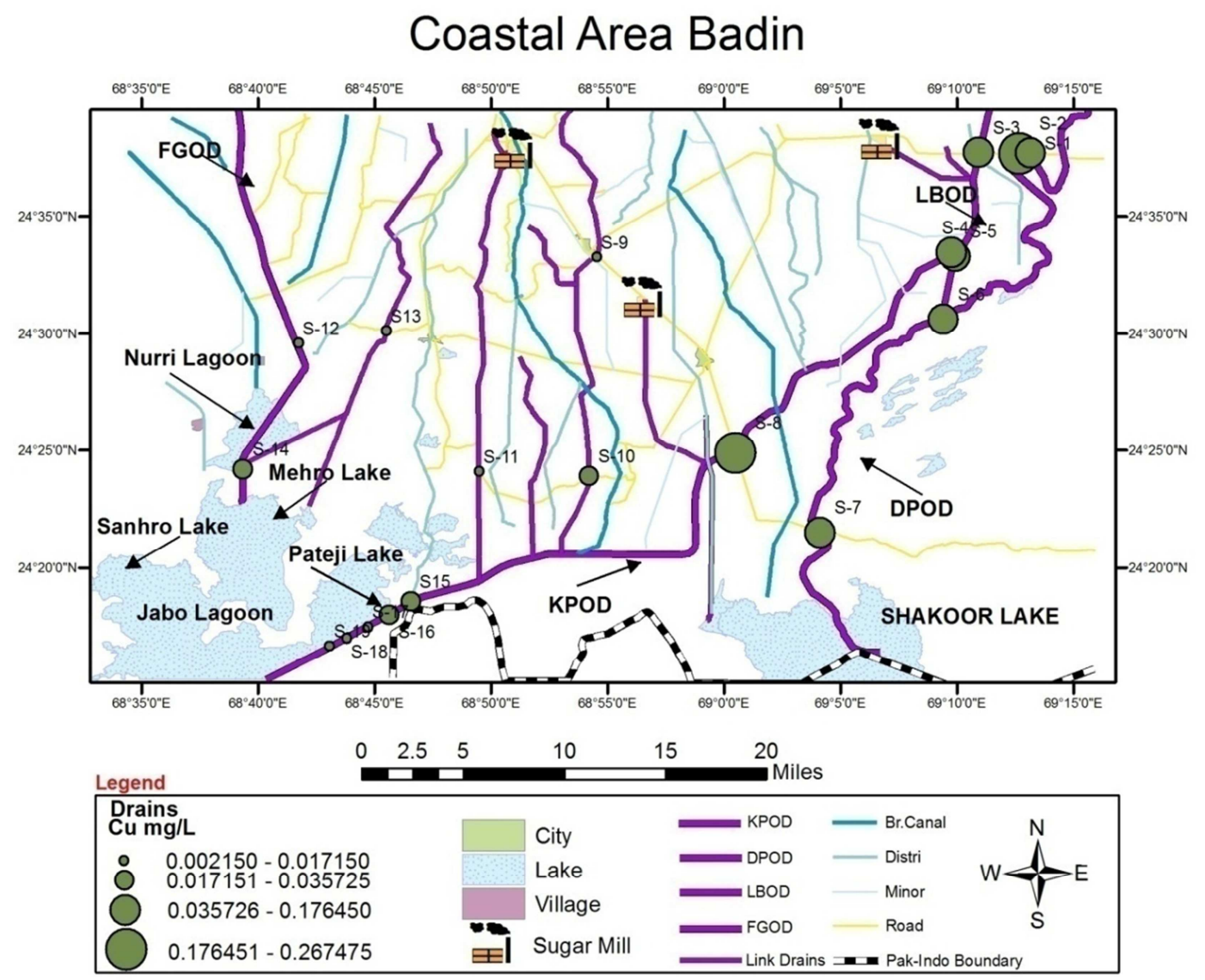

Fig. 9. Map showing copper detection.

The Results of concentration of cadmium are showing Fig6, ranged between $0.00148-0.0698 \mathrm{mg} / \mathrm{L}$. The cadmium concentration in all sampling areas was found to be within limits $(0.1 \mathrm{mg} / \mathrm{L})$ set by NEQS. High concentration of Cd was observed at sampling area S-1, S-2.Concentration of cadmium was found to be diluted where KPOD enters near disappeared Cholri weir area (Fig.1).The cadmium concentration in all sampling areas was also found to be within permissible limits of FAO $(0.1 \mathrm{mg} / \mathrm{L})$ for agriculture use [18].According a study conducted for industrial effluent near Karachi, reported concentration of $\mathrm{Cd}$ was 0.004-2.4 $\mathrm{mg} / \mathrm{L}$, by Saif et al. [17]. Similar results were also reported by Tariq et al.[19] andAli et al. [24] for assessment of industrial and sewage effluents.According Iqbal and Edyvean,Khuhawar and Majidano, Devnani and Satsangee, andIqbal et al.[20,21,22 and 23] the major sources of $\mathrm{Cd}$ contamination are batteries, fertilizers,electroplating, smelting, paint pigments, mining and alloy industries.Though only sugar mill industries can be traced in district Badin(Fig 1),to find out other industries contributing cadmium pollutantsis very dificult task for present study, as LBOD caries industrial effluent of three distrits which are hundreds of km away from present study of areas.

The results of concentration of Zinc are shown in Fig 7, with graduated green circles, ranged from $0.0093-0.1227$ $\mathrm{mg} / \mathrm{L}$, divided within four classes. Zinc was within permissible limits $(5 \mathrm{mg} / \mathrm{L})$ of NEQS in all the sampling areas. Same reducing pattern of Zinc concentration was found as water quantity increased near coastal mixing zone (Fig 1).Zinc concentration in all the sampling areas was also within permissible limits of FAO $(2 \mathrm{mg} / \mathrm{L})$ for agriculture use[18].Similar results for zinc concentration were also found by $[17,19,24] . I t$ has been reported that exceeded concentration of zinc in water bodies, causes fever, depression, malaise, cough, vomiting and headache $[25,26]$.

The results of the concentration of Iron as shown in Fig8, presented in measured green color circles, ranging concentration from $0.0112-0.177 \mathrm{mg} / \mathrm{L}$. The result values obtained in all sampling stations are within NEQS $(8 \mathrm{mg} / \mathrm{L})$ limits for municipal and industrial effluents. It is obvious that the concentration of iron was higher near entrance of drain and it reduced on reaching the coastal sea water mixing zone (Fig 8). It may be due to high quantity of water near coast, causing heavy metal concentration get diluted.Iron concentration in all the sampling areas was also within permissible limits of FAO $(5 \mathrm{mg} / \mathrm{L})$ for agriculture use [18].The results of the concentration of $\mathrm{Fe}$ are in agreement with Saif et al. [17].Similar findings were also reported by Tariq et al. [19] and Ali et al. [24].

The result of the concentration of copper indicated in figure 9. Copper was found to be within range $(1 \mathrm{mg} / \mathrm{L})$ ofNEQS for industrial effluents, of sampling areas. The result of copper concentration was ranged from0.002-0.267 $\mathrm{mg} / \mathrm{L}$.It is obvious in figure that the concentration of copper was higher near entrance path of mega drains and it reduced on reaching the coastal sea water. The concentration of 
copper in all the sampling areas except S-2 and S-8 was found within permissible limits of FAO $(0.2 \mathrm{mg} / \mathrm{L})$ for agriculture use [18].According Elenhorn and Barceloux [27] mostly water contamination of copper occurs due to untreated industrial wastewater pollution.

\section{Conclusion}

Pollution caused by LBOD,and link drains of the coastal areas of Badin have caused great problems. A positive approach for understanding the situation was developed by using GIS software. GIS maps revealed the extent of concentration of contaminatingpollutantsof drains and link drains of the coastal areas.Present study of drainsrevealed that main LBOD, KPOD, DPOD as well as link drains are carriers of pollutants including heavy metals. They bring industrial effluents,along with, pumped saline water, agriculture run off, and municipal waste water. Present study indicated that heavy metals are present within NEQS limits for municipal and industrial effluents of Pakistan.Low detection of heavy metal concentration in KPOD and DPOD is because of huge flow of water quantity exceeding 2000 cusecs, most of times. Therefore heavy metal concentration gets diluted.It was observed that at near coastal wetlands, the heavy metal pollutants were found in low concentration due to presence of excess tidal sea water. The Phenomenon for TDS and E.C was very opposite as compared with those of heavy metals.All drains indicated that they are very saline. High concentration of TDS, and E.C, near the coastal sampling areas confirms that sea water has been facilitated with backward flow by same drains due to sea tides.Poor infrastructure of LBOD has polluted the coastal zone, mostly due breaches in KPOD near zero point and completely disappearance of tidal link and cholri weir infrastructures. The results were found to be within limits of NEQS and FAO for industrial and agriculture purposes respectively.Hence water of LBOD can be used as a saline agriculture if other contaminants checked properly according to NEQS of Pakistan.

\section{References}

[1] SIDA,"Sindh Water Sector Improvement Project-I.Regional master plan of Indus delta and coastal zone. Revival of Natural Dhoras"Sindh Water Sector Improvement Plan for Left Bank of Indus, Delta and Coastal Zone, 2013.

[2] EIA,"Environmental Impact Assessment for Exploration Activities in Badin Concession" - Protected Area Final report, 2012.

[3] [3]LBOD,"Review of the performance of the Left Bank Outfall Drain Stage IKPOD, DPOD, Tidal Link and Cholri Weir" Report of the World BankInternational Panel Experts, POE Report,2005.

[4] M. Memon, M. S.Soomro , M. S. Akhtar,K.S. Memon"Drinking water quality assessment in Southern Sindh (Pakistan)" Journal of Environmental Monitoring Assessment,2010.doi: 10.1007/s10661-010-1616-z.
[5] IUCN,"District Vision Badin A Framework for Sustainable Development"2006.

[6] S.M. Leghari,S.I.H. Jafri,A .Mahar,K. H. Lashari ,S.S. Ali,T.M. Jahangir, and M.Y. Khuahawar"Limonological study of Sanhro,Mehro,Pateji and Cholri lakes of district Badin ,Sindh, Pakistan" Pakistan Journal BiologyScience,vol.3 pp1904-1909, 2000

[7] M.A. Qureshi and G.M.Mastoi“The physiochemistry of sugar mill effluent pollution of coastlines in Pakistan" Ecological Engineering,vol. 75pp 137-144, 2015

[8] [8]SIDA,"Sindh Water Sector Improvement Project-I. Regional master plan of Indus delta and coastal zone (WSIP-I), Preparation of regional plan for the left bank of Indus, Delta and Coastal Zone Main report final - Phase - II" Sindh Irrigation and Drainage Authority 2012.

[9] DDRMP,“District Badin: District Disaster Risk Management Plan Badin, Sindh Province Second Draft District Badin, Sindh" UNDP for DDRMP District Badin ,2007.

[10] NDP,"Management report and recommendation in response to the inspection panel investigation report Pakistan: National Drainage Program" Project International Bank for Reconstruction and Development, International Development Association 2006.

[11] APHA, "Standard Methods for the Examination of Water and Wastewater" 17th ed. American Public Health Association, Washington D C , 1989.

[12] P.A. Burrough,"Principles of Geographic Information System for land Resources Assessment Monograph on Soils and Resources Survey No. 2" Clarendon Press, Oxford, England 1986.

[13] H.M.Baalousha,"Mapping groundwater contamination risk using GIS and groundwater modeling: A case study from the Gaza Strip, Palestine" Arabian Journal of Geosciences,vol.4 pp 483 - 494, 2011.

[14] M.O. Arnous\& A.E. El-Rayes, “An integrated GIS and hydro chemical approach to assess groundwater contamination in West Ismailia area, Egypt" Arabian Journal of Geosciencesvol. 6:pp2829- 2842, 2013.

[15] A. Facchinelli,E. Sacchi, L. Mallen,"Multivariate statistical and GIS-based approach to identify heavy metal sources in soils”. J. Environ. Pollut. Vol. 114,pp 313-324, 2001.

[16] F. Wang, "Quantitative Methods and Applications in GIS" Taylor \& Francis, New York,2006.

[17] M. S. Saif, Midrar-ul-Haq ， K.S.Memon,"Heavy Metals Contamination through Industrial Effluent to Irrigation Water and Soil in Korangi Area of Karachi Pakistan"Internationa Journal of Agrriculture andBiology, vol. 4pp 646-648,2005.

[18] A.A. Othman, S.A.Rabeh,M. Fayez,M, Monib,N.A. Hegazi,"El-Salam canal is a potential project reusing the Nile Delta drainage water for Sinai desert agriculture: Microbial and chemical water quality"Journal of Advance Research pp99-108,2012.

[19] M. Tariq, M. Ali, Z. Shah, "Characteristics of industrial effluents and their possible impactson quality of underground water"Soil \& Environment,vol. 25pp 64-69,2006.

[20] M.Iqbal, R.G.J. Edyvean, "Loofah sponge immobilized fungal biosorbent a robust system for cadmium and other dissolved metal removal from aqueous solution" Chemosphere, vol. 61, pp 510-518,2005. 
[21] M. Y. Khuhawar and S. A. Majidano,"An Investigation of Quality of Groundwater of TalukaNawabshah" Pakakistan Journalof Chemistery vol. 1(2)pp 65-71,2011.

[22] H. Devnani, S.P.Satsangee,"Green gold nano particle modified anthocyanin-based carbon paste electrode for voltammetric determination of heavy metals"International Journal of Environmental Science and Technology. 2014. DOI10.1007/s13762-014-0497-z

[23] M. Iqbal, A. Saeed, S.I. Zafar,"Hybrid biosorbent: an innovative matrix to enhance the biosorption of $\mathrm{Cd}(\mathrm{II})$ from aqueous solution" Journal of Hazard Materials.vol.148pp 47$55,2007$.

[24] H.M. Ali, E.M. EL-Mahrouk, F.A. Hassan, M.A.ELTarawy,"Usage of sewage effluent in irrigation of some woody tree seedlings. Part 3: Swieteniamahagoni (L.) Jacq" Saudi Journal of Biology and Science,vol.18,pp 201-207. 2011.

[25] M. Shakirullah , I. Ahmed, K.Mehmood , A .Khan , H. Rehman , S. AlamA. A. Shah,"Physicochemical Study of Drinking Water from Dir Districts" Journal of Chemical Society of Pakistan vol. 27(4), pp 374-387,2005.

[26] S.Farid,M.K. Baloch and S.A. Ahmad "Water pollution: Major issue in urban areas" International Journal of Water Resources and Environmental Engineering vol. 4,pp5565,2012 .

[27] M. J. Ellenhorn,D.G.Barceloux,"Medical toxicology: diagnosis and treatment of human poisoning", New York, Elsevier Science publishing company 1988. 